\title{
Article/Artigo
}

\section{High prevalence of HTLV-1 and 2 viruses in pregnant women in São Luis, State of Maranhão, Brazil}

\author{
Alta prevalência dos vírus HTLV-1 e 2 em gestantes de São Luis, Estado do Maranhão, Brasil
}

\author{
Verônica Guimarães de Souza ${ }^{1}$, Marina Lobato Martins ${ }^{2}$, Anna Bárbara de Freitas Carneiro-Proietti², \\ José Nélio Januário ${ }^{3}$, Roberto Vagner Puglia Ladeira ${ }^{3}$, Camila Moreira Serra Silva ${ }^{1}$, Claudyene Pires ${ }^{1}$, \\ Samea Cristina Gomes ${ }^{1}$, Christiane de Souza Martins ${ }^{1}$ and Elba Gomide Mochel $^{1}$
}

\begin{abstract}
Introduction: Human T cell lymphotropic virus type 1 (HTLV-1) is endemic in the Caribbean, Japan, South America and regions of Africa. HTLV-2 is present in Native American populations and associated with IV drug use in Europe and North America. In Brazil, it is estimated that 1.5 million people are infected with HTLV-1/2. The study objective was to determine HTLV-1/2 prevalence in pregnant women in the prenatal care from three public services in São Luis, State of Maranhão, Brazil, and to counsel seropositive women to reduce viral transmission. Methods: A cross-sectional study was conducted from February to December 2008; women with age of 18 to 45 years, with low risk for sexually transmitted disease (STD) were invited to participate. Blood samples were collected in filter paper, and HTLV-1/2 immunoenzymatic test (ELISA) was performed as a screening test. Women with reactive results were submitted to peripheral venous blood collection for ELISA repetition, followed by Western blot (WB) and real-time PCR to confirm and discriminate the infection between virus types 1 and 2. Results: Of the 2,044 women tested, seven $(0.3 \%)$ were ELISA reactive and confirmed positive (four were HTLV-1, and three were HTLV-2). All positive women were oriented not to breastfeed their newborns. Conclusions: This study showed that the virus is present in high prevalence in that population. Further studies covering other segments of the population are necessary to better characterize the presence of HTLV-1/2 in Maranhão and to elicit measures to prevent its spread.
\end{abstract} Keywords: HTLV-1/2. Pregnancy. Prevalence. Maranhão. Brazil.

\section{RESUMO}

Introdução: O vírus linfotrópico de células T humanas tipo 1 (HTLV-1) é endêmico no Caribe, Japão, América do sul e regiões da África. O HTLV-2 está presente em populações indígenas das Américas e usuários de drogas injetáveis na Europa e América do Norte. No Brasil, estimase que 1,5 milhões de pessoas estejam infectadas pelo HTLV-1/2. O objetivo deste estudo foi de determinar a prevalência do HTLV-1/2 em gestantes atendidas no pré-natal de três serviços públicos em São Luis, Maranhão, e orientar as mulheres soropositivas para reduzir a transmissão viral. Métodos: Foi realizado um estudo transversal, de fevereiro a dezembro de 2008, com gestantes de 18 a 45 anos, com baixo risco de doença sexualmente transmissível (DST). Amostras de sangue foram coletadas em papel filtro e submetidas à técnica de ensaio imunoenzimático (ELISA) como teste de triagem para HTLV-1/2. As gestantes com resultado ELISA reativo foram submetidas à coleta de sangue venoso periférico para repetição do ELISA, seguido por WB e PCR em tempo real para confirmar e discriminar a infecção pelos tipos virais. Resultados: Das 2.044 mulheres examinadas, sete (0.3\%)tiveram resultados reativos e foram confirmadas soropositivas (quatro para HTLV-1 e três para HTLV-2). Todas as sete gestantes foram orientadas a não dar leite materno aos filhos. Conclusões: Este estudo mostrou que o HTLV-1/2 está presente em alta prevalência na população das mulheres grávidas estudadas. São necessários outros estudos contemplando diferentes segmentos populacionais para caracterizar a presença do HTLV-1/2 no Maranhão, e permitirmedidas preventivas contra a disseminação viral.

Palavras-chaves: HTLV-1/2. Gravidez. Prevalência. Maranhão. Brasil.

1. Mestrado Materno Infantil, Departamento de Enfermagem, Universidade Federal do Maranhão, São Luís, MA. 2. Núcleo de Pesquisa, Fundação Hemominas, Belo Horizonte, MG. 3. Núcleo de Ações e Pesquisa em Apoio Diagnóstico, Faculdade de Medicina, Universidade Federal de Minas Gerais, Belo Horizonte, MG. Addressto: Dra. Verônica Guimarães de Souza. Dept ${ }^{\circ}$ Enfermagem/UFMA. Praça Gonçalves Dias s/n, 65020-240 São Luis, MA, Brasil.

Phone: 5598 3231-7410

email: vero_guima@hotmail.com

Received in 13/08/2010

Accepted in 08/08/2011

\section{INTRODUCTION}

A serious health issue in the perinatal period is the transmission of pathogens because it frequently causes diseases in both mother and fetus/newborn. In Brazil, epidemiologic information about infections transmitted during the perinatal periods is scarce, especially in the northeast region. One of these infections may be caused by human $\mathrm{T}$ cell lymphotropic virus (HTLV) ${ }^{1,2}$.

Although the exact number of HTLV-infected individuals is not known, it is estimated that 15 to 20 million people in the world are infected by the virus $^{1,3}$. The prevalence rates differ according to the geographical area, sociodemographic distribution of the studied population, and risk behavior of the individual. HTLV-1 is endemic in the Caribbean, Japan, South America, and regions of Africa, whereas HTLV-2 is more common among native American groups but rare in Africa and is associated with intravenous drug use in Europe; it also is more prevalent in Brazilian Indian populations ${ }^{4-6}$. Prevalence rates of HTLV vary considerably from country to country and even within the same country, in different areas ${ }^{3}$. Japan is the country with the highest endemic index of the world for the virus, where its prevalence may reach $20 \%$ of the population in certain areas of the country. Other countries also have high levels of the infection, such as French Guinea (4.4\%), Peru (2.3\%), and Jamaica (5\%), which may vary with the population studied. In addition, the prevalence rates are considerably lower in nonendemic countries, like Spain (0.064\%) and the United Kingdom $(0.039 \%)^{1,2,7}$.

In Brazil, there is an estimation of 1.5 million infected people, what makes the country the one with the highest absolute number of seropositive individuals ${ }^{4-6}$. The virus prevalence increases with age and is higher in female than in male subjects. There is a tendency of familial accumulation concerning the incidence of HTLV infection and associated diseases ${ }^{8}$. 
HTLV is transmitted through breastfeeding, sexual intercourse without protection, blood transfusion, and sharing of contaminated syringes $5,6,9,10$. The diagnosis of the infection is performed through the identification of the antibodies anti-HTLV-1 and anti-HTLV-2 through immunoenzymatic assay (ELISA) and confirmatory tests, being Western blot (WB) the most commonly used, although polymerase chain reaction (PCR) is considered the golden standard for confirmation of the infection ${ }^{5,6,9,10}$.

The greatest interest in the prevention of HTLV is due to the virus association with diseases such as an aggressive form of adult $\mathrm{T}$ cell leukemia/lymphoma (ATL), a degenerative chronic neurologic syndrome (HTLV-associated myelopathy HAM/tropical spastic paraparesis-TSP) as well as other pathologies such as arthritis, uveitis, and infectious dermatitis ${ }^{9,10}$. The aim of this study was to identify the prevalence of the HTLV-1/2 infection in pregnant women in the prenatal care of three public services (São Luis, State of Maranhão, Brazil) and to evaluate the coinfection with human immunodeficiency virus (HIV) in seropositive HTLV patients, as well as the socioeconomic, demographic, and risk-behavioral factors in the analyzed population.

\section{METHODS}

\section{Study population}

A cross-sectional study was conducted from February to December 2008, and 2,044 pregnant women with age of 18 to 45 years and with low risk for sexually transmitted disease (STD) were analyzed. Because of the logistics of test results, women with pregnancies up to 22 weeks were selected. They were from three public services (University Hospital Materno Infantil, Maternity Hospital Benedito Leite, and Maternity Hospital Marli Sarney), where their prenatal care took place. Women with high-risk pregnancies were excluded because of the clinical and emotional issues already present. Those with previously diagnosed psychiatric disorder also were excluded because their judgment and decision to participate could not be entirely established. The patients were evaluated for socioeconomic and demographic aspects, and behavioral risk-factors. These women were all negative for the human immunodeficiency virus type 1 (HIV-1) (source of data: patient's medical files).

The population was considered finite, with a test power of $95 \%$ and an absolute error of $5 \%$. We used Stata 9.0 to analyze the collected data.

\section{Laboratory tests}

We collected dried blood samples in S\&S 903 filter paper and ELISA tested them using Q-Preven HTLV-1+2 - IgG (Bio-Rad, USA) according to the manufacturer's instructions. The tests were performed using Diagnostic and Research Center of Universidade Federal de Minas Gerais (NUPAD/UFMG), Brazil. We collected blood samples from reactive females in vacutainer tubes to confirm the results. ELISA tests (HTLV-1+2 Ab-Captures ELISA Test System; Ortho Clinical Diagnostic Inc, New Jersey, USA) were performed on the samples, and those that were reactive were tested with realtime PCR as described previously ${ }^{11}$ and Western Blot (HTLV Blot 2.4; MP Diagnostics, Singapore), according to the manufacturer's instructions, for diagnosis confirmation. The serological and PCR tests were performed in the Serology Laboratory and the Research Laboratory at Fundação Hemominas, respectively.

\section{Ethical considerations}

This study was approved by the institutional committee for ethics in Human Research from the Universidade Federal do Maranhão.

\section{RESULTS}

We invited 2,070 pregnant women to participate in the study, and 2,044 agreed to participate and were screened for HTLV. Approximately $53.8 \%$ of the women tested were from São Luis, and $41.1 \%$ were from other cities of Maranhão. Their mean age was 25 , ranging from 18 to 43 (Table 1).

Considering marital status, $56.2 \%$ were married or had a commonlaw union, $43 \%$ were single, and the majority had a steady sexual partner. Regarding the number of children, 55\% did not have children, and $41 \%$ had up to two children; $45 \%$ of the women had never been pregnant before; $54.2 \%$ reported the beginning of their sexual activity between the ages of 15 and 18 years. Thirty-five percent declared that they had never used a condom, and $19.8 \%$ declared they used it often.

Regarding lactation, $19.4 \%$ of them breastfed for 1 to 3 months, and $30.3 \%$ had never practiced cross breastfeeding; $3 \%$ reported having blood transfusions in the past, and $1.5 \%$ informed the use of illegal drugs.

Regarding self-reported skin color, $14.8 \%$ were white, $16.4 \%$ black, and $62.1 \%$ defined their skin color as being either mixed or other colors; $57.2 \%$ had studied for at least 11 years, but $9.1 \%$ went to school for less than 4 years.

Of the 2,044 samples tested, eight samples collected on filter paper were positive according to ELISA. In the second collection (peripheral blood) for the confirmatory test, the samples were retested using ELISA, revealing seven positive samples (0.3\%) and one

TABLE 1 - Epidemiologic characteristics and sexual or blood transmitted risk factors of 2,044 pregnant women submitted to HTLV screening, São Luis, State of Maranhão, Brazil, 2008.

\begin{tabular}{lcc}
\hline Characteristics & Frequency & Percentage \\
\hline Age (years) & & \\
$\geq 18 \leq 25$ & 999 & 48.9 \\
$\geq 26 \leq 35$ & 904 & 44.2 \\
$\geq 36 \leq 45$ & 141 & 6.9 \\
\hline Skin color & & \\
white & 303 & 14.8 \\
black & 336 & 16.5 \\
others & 1,405 & 68.7 \\
\hline Marital status & & \\
single & 884 & 43.3 \\
married/steady & 1,149 & 56.2 \\
divorced/widow & 11 & 0.5 \\
\hline Level of education & & 17.3 \\
elementary school & 351 & 72.9 \\
high school & 1,490 & 9.7 \\
postgraduate & 200 & 0.1 \\
no study & 3 & \\
\hline Partner's drug use & & \\
yes & 240 & \\
no & & \\
not known/not informed & 1,711 & \\
\hline HTLV: human T-cell lymphotropic virus. & \\
& & \\
\hline & & \\
\hline
\end{tabular}


indeterminate $(0.5 \%)$. All reactive samples were confirmed positive according to PCR: four $(0.2 \%)$ were found to be HTLV-1, and three $(0.1 \%)$ were HTLV-2. None was positive for HIV, as mentioned in the methods section.

Sociodemographic and behavioral characteristics of HTLVpositive individuals are presented in Table 2. Age in this group ranged from 19 to 36, and their level of education was high school or lower. One of them reported illegal drug use, and one had blood transfusion previously. None informed drug use in the partner, and all but one had begun sexual activity before they were 18 years old. All reported being passively breastfed, and one also had actively breastfed her child.

TABLE 2 - Epidemiologic characteristics of HTLV-infected pregnant women, São Luis, State of Maranhão, Brazil, 2008.

\begin{tabular}{|c|c|c|c|c|c|c|c|}
\hline $\begin{array}{l}\text { Subject } \\
\text { Characteristic }\end{array}$ & 1 & 2 & 3 & 4 & 5 & 6 & 7 \\
\hline Virus infection & HTLV-2 & HTLV-1 & HTLV-2 & HTLV-1 & HTLV-2 & HTLV-1 & HTLV-1 \\
\hline Age (years) & 20 & 36 & 32 & 22 & 19 & 26 & 19 \\
\hline Level of education & $\begin{array}{c}\text { finished } \\
\text { high school }\end{array}$ & $\begin{array}{l}\text { unfinished } \\
\text { high school }\end{array}$ & $\begin{array}{l}\text { finished high } \\
\text { school }\end{array}$ & $\begin{array}{c}\text { finished high } \\
\text { school }\end{array}$ & $\begin{array}{l}\text { unfinished } \\
\text { high school }\end{array}$ & $\begin{array}{l}\text { unfinished } \\
\text { high school }\end{array}$ & $\begin{array}{l}\text { unfinished high } \\
\text { school }\end{array}$ \\
\hline Skin color & yellow & white & mixed & other & other & other & mixed \\
\hline Beginning of sexual activity (age in years) & 15 to 18 & 15 to 18 & 15 to 18 & 15 to 18 & 15 to 18 & after 18 & $<15$ \\
\hline Use of condoms & sometimes & never & never & never & always & never & always \\
\hline Children (n) & none & 1 & 1 & none & none & none & 2 \\
\hline Blood transfusion & no & no & no & yes & no & no & no \\
\hline Illegal drug use & no & no & no & no & no & no & yes \\
\hline Partner's drug use & no & no & no & no & no & no & no \\
\hline Passive breastfeeding & mother $\quad r$ & other and others & $s$ mother & mother & mother & mother & mother \\
\hline Active breastfeeding & no & no & yes & no & no & no & no \\
\hline
\end{tabular}

\section{DISCusSION}

The prevalence of HTLV-positive individuals in this population $(0.3 \%)$ is considerably higher than that found in blood donors. It is interesting to note that it is reported in the literature that the prevalence of HTLV infection is higher in women and that blood donors in Brazil tend to have a high proportion of males and are not representative of the general population ${ }^{2,3}$. We did not find coinfections by HTLV and HIV; nevertheless, it is important to emphasize that the HIV test results were checked in the medical records, and therefore, we did not have access to the methods utilized.

HTLV presence in the population of this study was three times higher than the one found in previous Brazilian studies investigating HTLV prevalence among pregnant women from the regions of Mato Grosso do Sul $(0.1 \%)^{1,12}$ and Botucatu, State of São Paulo $(0.1 \%)^{13}$. Studies on HTLV prevalence performed in Salvador, State of Bahia ${ }^{14,15}$, found a higher prevalence rate in pregnant women $(0.8 \%)$ than the one found from the ones previously mentioned.

Low socioeconomic status markers, such as few years of education, are associated to the infection by HTLV-1 in endemic and nonendemic areas. This suggests that the social and environmental factors associated to poverty may influence the virus transmission and maintenance in the population ${ }^{3}$.

There was no statistical significance in the correlation of the reactivity and no reactivity in the screening test with regard to marital status or age ( $p$ value of 0.76 and 0.82 , respectively), data in accordance with a study conducted at a region in Bahia, Brazil, which was done with a much smaller sample (408 pregnant women) ${ }^{15}$.
In the present survey, $56.1 \%$ of the studied women are either single with a partner or married, in accordance with the data found in Salvador/BA by Moxotó (2007), which studied the sociodemographic profile of pregnant women (who were being studied for HTLV infection), finding 53\% of single pregnant women.

The studied sample revealed that $54.2 \%$ began sexual activity between the age of 15 and 18 years; in Botucatu, $55.3 \%$ of the studied women began sexual activity before the age of 18 years. According to Olbrich Neto e Meira, the precocious beginning of sexual activity may increase the risk of acquiring sexually transmitted diseases (STDs), making it also a risk factor for HTLV-1 infection.

Among the pregnant women, $57.1 \%$ declared to have completed high school, a fact that matches the data found in previous studies ${ }^{14}$. The survey points out that $79.8 \%$ would sometimes or never use condoms during sexual intercourse, and $1.2 \%$ have used illegal drugs, what is confirmed by the study of Moxoto in which $83 \%$ of the women declared either not to use condoms or to rarely do so, and $1.5 \%$ admitted the use of illegal drugs. The results of the survey also are in accordance with the ones found in a study done in HTLV seropositive women in Salvador, in which they also stated the irregular or none existent use of condoms.

We verified as well that $17.1 \%$ of the women had been breastfed by other people (passive breastfeeding), data in accordance with the findings by Olbrich e Meira in a study about HTLV, HIV, syphilis, and toxoplasmosis prevalence in São Paulo, in which they verified a frequency of $10 \%$ of passive cross breastfeeding.

We identified a connection between passive cross breastfeeding practice and the region of birth of the woman, as $54.2 \%$ of the women reporting cross breastfeeding were born in the countryside of Maranhão, which may reflect a cultural or socioeconomic reality 
of the state. It would be interesting, in further Brazilian studies, to address this issue, which has an impact in preventive measures.

In conclusion, we recommend further studies covering other groups, ideally population studies aimed at identifying the actual situation of the virus infection in the state to determine the need of implementing mandatory HTLV screening in prenatal care, similar to what is currently done for HIV. There also is a need of increasing the awareness of the population, health authorities, and even the health staff regarding HTLV and the diseases it may cause, because the authors detected a low level of knowledge regarding the virus.

\section{ACKNOWLEDGMENTS}

The authors thank Ms. Cissa Soares for critically reviewing the manuscript.

\section{CONFLICT OF INTEREST}

The authors declare that there is no conflict of interest.

\section{FINANCIAL SUPPORT}

Fundação de Amparo à Pesquisa do Estado de Minas Gerais (FAPEMIG).

\section{REFERENCES}

1. Figueiró-Filho EA, Lopes AHA, Senefonte FRA, Souza Jr VG, Botelho CA, Duarte G. Infecção pelo vírus linfotrópico de células $\mathrm{T}$ humana e transmissão vertical em gestantes de estado da Região Centro-Oeste do Brasil. Rev Bras Ginecol Obst 2005; 27:719-725.

2. Gonçalves DU, Proietti FA, Ribas JGR, Araújo MG, Pinheiro SR, Guedes AC, et al. Epidemiology, Treatment, and Prevention of Human T-Cell Leukemia Virus Type 1-Associated Diseases. ClinMicrobiol Rev 2010; 23:577-589.

3. Proietti FA, Carneiro-Proietti ABF, Catalan-Soares BC, Murphy EL.Global epidemiology of HTLV-1 infection and associated diseases. Oncogene 2005; 24:6058-6068.

4. Ades AE, Parker S, Walker J, Edginton M, Taylor GP, Weber JN. Human T cell leukemia/lymphoma virus infection in pregnant women in the United Kingdom: population study. Br Med J2000; 320:1497-1501.

5. Bangham CRM, Osame M. Cellular immune response to HTLV-1. Oncogene 2005; 24: 6035-6046

6. Barcellos NT, Fuchs SC, Mondini LG, Murphy EL. Human T lymphotropic virus type I/II infection Prevalence and risk factors in individuals testing for in counseling centers from southern Brazil. Sexually transmitted Dis 2006; 33:302-306.

7. Magalhães TS. Prevalência da infecção pelo vírus linfotrópico de células T humanas (HTLV) tipo-1 em gestantes de uma cidade do Recôncavo Baiano. Rio de Janeiro: Rev Bras Ginecol Obstet 2007; 29:166.

8. Catalan-Soares BC, Proietti ABFC, Proietti FA. Vírus-T linfotrópico humano em familiares de candidatos a doação de sangue soropositivos: disseminação silenciosa. Rev Panam Salud Publica 2004; 16:387-394.

9. Bittencourt AL. Vertical transmission of HTLV-I/IIA review. Rev Inst Med Trop 1998 ; 40:245-251

10. Bittencourt AL, Primo J, Oliveira MFP. Manifestações infanto-juvenis da infecção pelo vírus linfotrópico de células T humanas (HTLV-I). J Pediatr 2006; 86:411-420.

11. Andrade RG, Ribeiro MA, Namen-Lopes MSS, Silva SMN, Basques FV, Ribas JG, et al. Evaluation of the use of real-time PCR for human T cell lymphotropic virus 1 and 2 as a confirmatory test in screening for blood donors. Rev Soc Bras Med Trop 2010; 43:111-115.
12. Dal Fabbro MMFJ, Cunha RV, Bóia MN, Portela P, Botelho CA, Freitas GMB, et al. Infecção pelo HTLV 1/2: atuação no pré-natal como estratégia de controle da doença no Estado de Mato Grosso do Sul. Rev Soc Bras Med Trop 2008; 41:148-151.

13. Olbrich Neto J, Meira DA, Alves D. Soroprevalência de vírus linfotrópico de células T humanas, vírus da imunodeficiência humana, sífilis e toxoplasmose em gestantes de Botucatu - São Paulo - Brasil. Fatores de risco para vírus linfotrópico de células T humanas. Rev Soc Bras Med Trop 2004; 37:28-32.

14. Moxotó I, Boa-Sorte N, Nunes C, Mota A, Dumas A, Dourado I, et al. Perfil sócio demográfico, epidemiológico e comportamental de mulheres infectadas pelo HTLV-1 em Salvador-Bahia, uma área endêmica para o HTLV. Rev Soc Bras Med Trop 2007; 40:37-41.

15. Kashiwagi K, Furusyo N, Nakashima H, Kubo N, Kinukawa N, Kashiwagi S, et al. A decrease in mother-to-child transmission of human $\mathrm{T}$ lymphotropic virus type I (HTLV-I) in Okinawa, Japan. Am J Trop Med Hyg 2004; 70:58-163. 